\title{
PENGARUH METODE HEARTH DALAM MODIFIKASI DIET PADA BALITA DENGAN MALNUTRISI
}

\author{
Wini Hadiyani $^{1}$ Agus Hendra $^{2}$ Linlin Lindayani $^{3}$ \\ Sekolah Tinggi Ilmu Keperawatan PPNI Jawa Barat \\ E-mail :winhad@yahoo.com
}

\begin{abstract}
ABSTRAK
Model Tungku (Hearth) merupakan salah satu pendekatan yang efektif dalam mengatasi gizi buruk karena berbasis empowering dan pembelajaran bagi masyarakat bahwa dalam pemecahan masalah sosial sebenarnya solusi ada di dalam masyarakat itu sendiri. Penelitian ini bertujuan untuk mengetahui pengaruh penerapan model tungku (Hearth) dalam meningkatkan status gizi balita malnutrisi melalui modifikasi diet. Jenis penelitian ini adalah Quasi eksperimen tanpa pembanding dengan tehnik one group pre test and post test design. Sampel didapatkan sebanyak 17 balita dengan tehnik purposive sampling. Status gizi balita dianalisa menggunakan pendekatan standar antropometri balita berdasarkan ambang batas (Z-score). Hasil uji T menunjukkan adanya pengaruh model hearth terhadap status gizi balita dengan $\mathrm{p}$ value $0,00(\mathrm{p}<0,05)$. Nilai beda didapatkan sebesar 1,482. Kesimpulannya adalah pendekatan model Hearth memberikan pengaruh yang signifikan terhadap perubahan status gizi pada balita malnutrisi
\end{abstract}

Kata Kunci : balita, model tungku (hearth), malnutrisi,

\begin{abstract}
Hearth methode is one of effectives method to solve malnutrition which based on community empowering. This method actually came from the communities solution. The opportunity of this research is to know the influencing of Hearth model on increasing of nutrition statue of underfive children with malnutrition by diet modification. This research use quasi experiment without comparing by one group pre-test and post-test design. The sample are 17 underfive children using purposive sampling and analyzed by antropometri standard based on Z-score level. The result by using T-test showed that hearth model has influence to nutrition statue of underfive children with p-value 0,00(p<0,05). The difference score is I,482. The conclusion is Hearth model given significant influencing of the nutrition statue of underfive children with malnutrition
\end{abstract}

Key word: Hearth methode, nutrition statue, underfive children

\section{PENDAHULUAN}

Gizi buruk merupakan status kondisi seseorang kekurangan nutrisi, atau status gizi di bawah standar rata-rata. Menurut Depkes (2011) dampak dari gizi buruk ini bisa menyebabkan KEP (Kurang Energi Protein), KEK (Kurang Energi Energi Kalori), balita akan menjadi lebih rentan terhadap infeksi, menyebabkan munculnya penyakit kronis, dan dapat menyebabkan adanya hambatan dalam pertumbuhan. Anak yang menderita gizi buruk mempunyai ratarata IQ 11 point lebih rendah dibandingkan rata-rata anak-anak yang tidak stunted. Dampak terhadap pertumbuhan otak ini menjadi vital karena otak adalah salah satu 'aset' yang vital bagi anak untuk dapat menjadi manusia yang berkualitas di kemudian hari.

Pemerintah telah melaksanakan berbagai upaya untuk meningkatkan derajat kesehatan dan status gizi balita yaitu melalui Posyandu (pemantauan pertumbuhan balita), penyuluhan kesehatan, konseling menyusui dan makanan pendamping ASI serta pemberian Makanan Tambahan (PMT). Akan tetapi dengan pendekatan PMT ini kurang berhasil, ketika gizi anak sudah membaik program pemberian makanan tambahan itu di hentikan dari pemerintah sehingga kondisi balita kembali mengalami 
gizi buruk ketika program dihentikan (Depkes, 2011).

Gizi buruk merupakan sebuah outcome yang sangat kompleks yang berhubungan dengan faktor perilaku, sosial, psikologi dan fisiologi di masyarakat, rumah tangga dan perorangan. Sebenarnya penyebab gizi buruk besar kaitanya dengan perilaku keluarga dalam pengasuhan anak, pemberian makan, perilaku kebersihan dan perawatan kesehatan. Sehingga saat ini berkembangan pendekatan baru yang berakar dari teori Social-Cognitive-Behaviour yaitu Pendekatan tungku adalah Metode Hearth yang telah berhasil di beberapa negara seperti Vietnam, Haiti, Bangladesh, Thailand. Metode Hearth ini membuat konfilasi antara konseling gizi keluarga dan pemberian makan anak dengan menggunakan dapur bersama (Sirajuddin, 2005).

Metode Hearth merupakan salah satu pendekatan yang efektif dalam mengatasi gizi buruk karena berbasis Empowering dan pembelajaran bagi masyarakat bahwa dalam pemecahan masalah sosial sebenarnya solusi ada di dalam masyarakat itu sendiri. Pemberdayaan masyarakat menjadi hal yang penting dalam upaya pendewasaan bagi masyarakat khususnya Negara berkembang sehingga dengan penggunaan Metode Hearth akan dapat menghemat anggaran biaya yang dikeluarkan oleh pemerintah untuk mengurangi angka gizi buruk karena pendekatan ini pada dasarnya tidak membutuhkan terlalu banyak biaya operasional karena direncanakan, dilaksanakan, dan dievaluasi oleh masyarakat.

Pendekatan tungku (hearth) dikembangkan oleh Monique dan Jerry Sternin (1990) yang berakar dari teori Social-CognitiveBehaviour dari Bandura. Terdapat 4 Perilaku yang dikembangkan dalam Metode Hearth, yaitu:

(1)Perilaku Pemberian Makanan

(2) Perilaku Kebersihan
(3)Perilaku Pengasuhan

(4) Perilaku Perawatan Kesehatan

Proses penerapan model tungku meliputi beberapa tahap, dimana tahap tersebut dilakukan agar pelaksanaan model ini disesuaikan dengan potensi sumber daya yang ada di masyarakat tersebut. Adapun proses pelaksanaan Metode Hearth meliputi:

\section{Tahap persiapan}

Melakukan musyawarah dengan masyarakat/ tokoh masyarakat mengenai gambaran kesehtan dan status gizi wilayahnya serta memberikan penjelasan mengenai Metode heart yang kemudian dibentuk "komite kesehatan desa". Menyusun rencana kerja komite desa serta persiapan di lapangan dan pelatihan kader tentang penanggulangan gizi kurang/buruk melalui Metode Hearth. Persiapan ini dilakukan sebelum pelaksanaan kegiatan inti. Secara teknis persiapan membutuhkan waktu 1-2 minggu tergantung pada kondisi masyarakat setempat.

\section{Pelaksanaan}

Pelaksanaan dimulai dengan pertemuan kader dan para tokoh masyarakat serta ibu dengan anak balita. Dilakukan penimbangan pada seluruh balita sehingga didapatkan status gizi balita. Setelah didapatkan hasil dilanjutkan pertemuan dengan ibu dan balita yang memiliki status gizi kurang/buruk. Pertemuan dilakukan selama 2-3 hari dilakukan berbagi pengalaman mengenai perilaku kesehatan baik dengan cara penyuluhan, demontrasi konseling dan pemberian permainan edukatif. Hari selanjutnya selama 12 hari disepakati pelaksanaan kegiatan sesuai dengan pengetahuan yang didapatkan. Para kader (sukarelawan) mengadakan monitoring terhadap ibu balita setiap hari berturut-turut meliputi pemberian makan, pola asuh, kebersihan dan perawatan kesehatan

Secara teknis kegiatan ini dilaksanakan setiap hari, kecuali hari Minggu selama 2 minggu berturut-turut. Hari Minggu kegiatan 
diliburkan, dengan maksud agar ibu mempunyai kesempatan sendiri untuk merawat balitanya. Setiap 2 minggu kegiatan, dilakukan jeda (pause) dan kegiatan baru dimulai kembali setelah dilakukan kegiatan penimbangan di Posyandu. Waktu istirahat ini dimaksudkan untuk mengajarkan ibu lebih mandiri dalam merawat balitanya dan mempraktekkan sendiri apa yang telah diperolehnya dalam kelompok pendekatan tungku (hearth). Berat badan balita akan segera termonitor dalam kegiatan Posyandu, apakah sudah terjadi peningkatan status gizi. Kegiatan teknis di dalam kelompok pun sangat aplikatif, disesuaikan kebutuhan dari masyarakat tersebut. Jenis makanan yang akan dimasak biasanya didiskusikan sehari sebelumnya oleh anggota kelompok. Bahan makanan dapat berasal dari para anggota kelompok maupun sumbangan langsung dari masyarakat (misalnya: pemilik warung menyumbangkan minyak tanah, dll).

\section{Monitoring dan Evaluasi}

Monitoring dan evaluasi dilaksanakan oleh Komite Kesehatan Desa, khususnya meliputi kehadiran dan kontribusi anggota pendekatan tungku (hearth) . Monitoring terhadap perubahan status gizi dilakukan dengan melihat hasil penimbangan berat badan pada hari pertama (baseline), hari ke12, dan saat kegiatan Posyandu. Monitoring perilaku baru di rumah peserta dilakukan oleh kader, serta evaluasi bulanan yang dilakukan bersama tokoh masyarakat. Evaluasi juga dilakukan melalui pertemuan bulanan di masyarakat (Marsh, 2008).

\section{METODE PENELITIAN}

Jenis Jenis penelitian ini adalah Quasi eksperimen tanpa pembanding dengan tehnik one group pre test and post test design . Penelitian ini bertujuan untuk mengetahui adanya pengaruh model Tungku (hearth) terhadap status gizi balita. Populasi dalam penelitian ini ibu dan balita dengan status gizi kurang di wilayah Kerja
Puskesmas Cimeyan kabupaten Bandung. Pengambilan sampel menggunakan purposive sampling dengan jumlah 17 responden dengan ktiteria :

(1) memiliki status gizi kurang

(2) tidak memiliki komplikasi dari gizi kurang (3) bersedia jadi responden.

Penilaian status gizi balita menggunakan pendekatan standar antropometri balita berdasarkan ambang batas (Z-score) (Kemenkes, 2010).

Pengumpulan data dilakukan dengan cara penimbangan berat badan sampel sebelum dilakukan penelitian kemudian dilakukan tahapan penerapan Metode Hearth dan untuk melihat keberhasilan proses tersebut setelah perlakukan dilakukan pengukuran kembali berat badan sampel.

Tahapan yang dilakukan dalam penerapan Metode Hearth.Secara teknis persiapan membutuhkan waktu 1-2 minggu tergantung pada kondisi masyarakat setempat. Intervensi berorientasi kepada perilaku pengasuhan, pemberian makan, kebersihan dan perawatan kesehatan.Setelah itu dilakukan monitoring dan pengukuran berat badan secara kontinyu. Analisa data yang digunakan dalam penelitian ini

1. Analisa Univariat

Analisis Univariat yaitu analisis status gizi balita sebelum dan sesudah dilaksanakan penanganan gizi buruk dengan penerapan Metode Heart data disajikan secara deskriptif dalam bentuk persentase. Dihitung presentasi dengan menggunakan rumus:

$$
P=\frac{f}{n} x 100 \%
$$

2. Analisa Bivariat

Analisis bi variat menggunakan uji beda dua mean dependent. Uji ini digunakan untuk melihat pengaruh penerapan Metode Hearth terhadap status gizi sebelum dilakukan tindakan (pre-test) dan status gizi setelah penerapan metode Hearth (post test)

Analisa Bivariat untuk mengetahui pengaruh penerapan metode Hearth terhadap status gizi pada balita yaitu yaitu menggunakan $\mathrm{Uji}$ 
$\mathrm{T}$ (T-test) dengan batas kemaknaan (nilai alpha) $5 \%$ untuk melihat hasil kemanaan perhitungan statistik digunakan batas kemaknaan 0,05. Penolakan terhadap hipotesis apabila $p$ value $\leq$ berarti ada pengaruh atau ada perbedaan bermakna, sedangkan gagal penolakan terhadap hipotesa apabila $p$ value $>0,05$ berarti tidak ada perbedaan / tiadak ada hubungan bermakna antara keduanya.

Rumus :

Uji beda dua Mean Dependent (Paired Sample Test)

$$
\mathbf{T}=\frac{\mathbf{d}}{\text { SD_d } / \sqrt{\mathbf{n}}}
$$

Etika penelitian ini meliputi :

a) Informed Consent

Informed Consent merupakan cara persetujuan antara peneliti dengan calon responden dengan memberikan lembar persetujuan. Peneliti menjelaskan tujuan penelitian kepada calon responden. Apabila calon responden bersedia menjadi responden maka dipersilahkan menandatangani lembar persetujuan, tetapi apabila calon responden tidak bersedia maka tidak ada pemaksaan untuk peneliti dengan keluarga calon responden yang tidak memungkinkan untuk memberikan persetujuan.

b) Anonimity

Anonimity merupakan etika penelitian dimana peneliti tidak mencantumkan nama responden pada lembar alat ukur, tetapi hanya menuliskan kode pada lembar pengumpulan data, kode yang digunakan berupa nomor responden (angka arab)

c) Confidentiality atau Kerahasiaan

Peneliti menjamin kerahasiaan hasil penelitian baik informasi maupun masalah lain yang menyangkut privasi klien. Hanya kelompok data tertentu yang akan dilaporkan pada hasil penelitian. Setelah penelitian selesai data dikumpulkan dan di bakar.

\section{HASIL PENELITIAN}

Perilaku Khusus dalam pemberian makan yang menjadi kebiasaan keluargayang 50 memiliki balita di wilayah puskesmas cimeyan adalah :

(1) memasak sendiri

(2) memberikan makanan selingan, seperti : goreng-gorengan, dan jajanan pasar

(3) makanan bervariasi

(4) frekuaensi makan 2-3x/hari

(5) ibu memiliki peranan penting dalam pemberian makan

(6) pemberian vitamin jika anak sulit makan.

(7) konsumsi makanan cepat saji

Kebiasaan dalam pengasuhan anak balita didapatkan:

(1) pola asuh tidak hanya oleh keluarga inti tapi ada peran nenek dan kakek

(2)kebiasaan menemani tidur anak

(3)menemani anak bermain dan belajar

(4) memberikan nasihat pada anak

Aktivitas dan fasilitas yang berkaitan dengan kebersihan pada keluarga dengan balita di eilayah cimeyan :

(1) mencuci tangan sebelum makan walaupun belum mengetahui cara cuci tanga yang baik

(2) mencuci sayuran dan buah sebelum dikonsumsi

(3) memiliki MCK sendiri di dalam rumah

(4) memandikan anak minimal $1 \mathrm{x} / \mathrm{hari}$

(5)membersihkan rumah

(6) tidak memiliki hewan ternak dekat rumah.

Pengkajian yang di dapatkan dalam perawatan kesehatan adalah ;

(1) masih terdapat pemberian immunisasi yang tidak lengkap

(2) bila anak sakit di bawa ke puskesmas

(3) belum mengetahui penanganan demam dan diare pada anak

1. Gambaran Status Gizi Balita

Tabel 1.1 Distribusi frekuensi status Gizi Balita sebelum dan sesudah dilakuka intervensi

\begin{tabular}{ccccccccc}
\hline $\begin{array}{c}\text { Status } \\
\text { gizi }\end{array}$ & \multicolumn{2}{c}{ Pre Tes } & \multicolumn{2}{c}{ Pos Tes } & \multicolumn{2}{c}{ Pos Tes 2} & \multicolumn{2}{c}{ Pos tes 3 } \\
& F & $\%$ & F & $\%$ & F & $\%$ & F & $\%$ \\
\hline $\begin{array}{c}\text { Gizi } \\
\text { baik }\end{array}$ & - & - & 5 & 29,4 & 13 & 76,5 & 15 & 88,2 \\
Gizi & 17 & 100 & 12 & 70,6 & 4 & 23,5 & 2 & 11,8 \\
Kurang & & & & & & & & \\
\hline
\end{tabular}


Tabel diatas menunjukkan adanya perubahan status gizi balita dai gizi kurang menjadi gizi baik di setiap tahapan metode hearth. Pada 12 hari pertama menunjukkan kenaikan status gizi sebesar $29,4 \%$ dan 12 hari kedua terjadi peningkatan sebesar 76,5\%. Perubahan Status gizi pada pengamatan terakhir yaitu 12 hari ke-3 setelah dilakukan intervensi menunjukkan sebagian besar yaitu $88,2 \%$ balita memiliki status gizi baik

Tabel 2.1 Analisis Perbedaan Status Gizi Sebelum dan sesudah dilakukan intervensi Metode hearth

\begin{tabular}{lcccc}
\multicolumn{3}{c}{ hearth } & \\
\hline & $\mathrm{N}$ Rerata \pm s.b. & $\begin{array}{c}\text { Perbedaan } \\
\text { rerata } \pm \text { s.b. }\end{array}$ \\
\hline Stat.Gizi & 17 & $10,00 \pm$ & & \\
sebelum & & 0,952 & & \\
& & & $-1,482$ & 0,000 \\
& & & $\pm 0,212$ &
\end{tabular}

$\begin{array}{lccc}\text { Stat.Gizi } & 17 & 11,48 \quad \pm \\ \text { setelah } & & 0,822\end{array}$

Berdasarkan table diatas hasil uji $t$ menunjukan $\mathrm{p}$ valuen $0,000 \quad(\mathrm{p}<0,05)$, dengan nilai beda sebesar 1,482 yang menunjukkan adanya perbedaan yang bermakna pada status gizi balita sebelum dan sesudah dialkukan intervensi dengan pendekatan model tungku (hearth). .

\section{PEMBAHASAN}

Perilaku ibu dalam pemberian makanan selingan terkadang tidak melihat kadar gizi yang terdapat pada makanan tersebut bahkan keluarga cenderung memberikan jajanan yang disukai anak untuk makanan selingan. Pemberian makanan selingan harus dikaji lagi karena keluarga belum mengetahui ciri jajanan sehat yang akan diberikan pada anak. Kebiasaan masak sendiri merupakan hal yang baik tapi cara memasak yang sehat belum dimiliki oleh keluarga seperti hilangnya zat gizi saat memasak karena kondisi yang terlalu matang atau cara memasak yang salah, misalnya menggunakan minyak goreng berkali-kali, menyatukan makanan yang mengandung vitamin yang saling menetralkan ataupun cara pencucian bahan baku yang salah sehingga menghilangkan kadar gizi dari makanan tersebut. Makanan yang bervariasi dan kebiasaan memberikan makan 2-3x sehari merupakan kebiasaan yang harus dipertahankan dalam keluarga namun keluarga tetap perlu memperhatikan kandungan gizi dalam porsi makanannya. Pemberian makanan cepat saji harus dikurangi sehingga keluarga harus memiliki pengetahuan yang cukup dalam pemilihan makanan cepat saji ataupun pembuatan makanan yang mudah murah, bergizi dan dapat menarik selera makan anak. Perilaku ibu yang kurang tepat dapat berdampak pada status gizi balita sesuai dengan penelitian dari Agus (2004) yang menyatakan perilaku $000_{\mathrm{ibu}}$ yang tidak tepat memilih bahan makanan dapat menyebabkan kekurangan gizi pada anak.. Peningkatan pengetahuan ibu dapat berpengaruh terhadap status gizi balita sesuai dengan penelitian Fisher, dkk (2012) menyatakan terdapat hubungan yang signifikan antara pengetahuan ibu tentang gizi terhadap status gizi balita.

Kebiasaan pola asuh yang dilakukan selain ibu juga ada peran anggota keluarga lain. Rahayu (2001) pengasuhan yang dilakukan oleh ibu akan lebih baik dibandingkan selain ibu karena menyebabkan perasaan lebih aman bagi anak. Perilaku mengenai kebiasaan pengasuhan keluarga terhadap balita yang dilakukan diperlukan modifikasi dengan pemberian mainan yang edukatif. Soetjahningsih (1995) alat permainan edukatif merupakan alat yang mengandung pendidikan sehingga dapat mengoptimalkan perkembangan anak secara fisik, bahasa dan kognitif. Penelitian Sain, dkk (2013) yang menyatakan adanya pengaruh alat permainan edukatif terhadap aspek perkembangan pada anak pra sekolah di Wilayah Puskesmas Ondong Kabupaten Kepulauan Siau Tagulandang Biaro.

Perilaku kebersihan yang biasa dilakukan oleh keluarga sudah baik namun peningkatan pengetahuan tentang cara yang 
tepat untuk mendapatkan kualitas yang baik. Kurangnya pengetahuan ibu mengenai immunisasi dan penanganan diare dan demam pun dapat berdampak pada status gizi balita. Sikap, keyakinan dan fasilitas kesehatan serta peran petugas kesahatan sangat berdampak pada perubahan perilaku kebersihan (Green 1980). Sikap yang positif pada masyarakat dan tersedianya posyandu serta keaktifan dari petugas kesehatan ataupun kader kesehatan menjadi potensi yang baik dalam perubahan perilaku keluarga.

Ke empat kebiasaan yang dilakukan oleh ibu dan keluarga berpengaruh pada status gizi balita. Status gizi pada balita secara langsung dipengaruhi oleh asupan makanan dan kondisi anak, dan secara tidak lansung dipengaruhi oleh pengetahuan ibu tentang gizi,pendapatan keluarga , pelayanan kesehtan, social budaya dan Sanitasi Lingkungan. (UNICEF, 2012)

Model tungku (hearth) ini memberikan pengetahuan pada ibu yang memiliki balita untuk meningkatkan pola asuh yang baik dalam pemberian makan dengan cara penyuluhan dan demonstrasi yang dilakukan oleh masyarakat setempat yang telah memiliki pengetahuan yang lebih baik kepada keluarga yang membutuhkan, diharapkan terjadinya peningkatan pengetahuan ibu dalam pola asuh pemberian makan. Pendekatan Metode tungku (hearth) merupakan upaya alternative yang dapat dilaksanankan untuk menjelaskan suatu keadaan penyimpangan positif yang berkaitan dengan kesehatan, pertumbuhan dan perkembangan anak-anak tertentu dengan anak-anak lain di dalam lingkungan masyarakat atau keluarga yang sama. Pendekatan model tungku (hearth) didasarkan pada asumsi bahwa beberapa solusi untuk mengatasi masalah gizi sudah ada di dalam masyarakat, hanya perlu diamati untuk dapat diketahui bentuk penyimpangan positif yang ada dari perilaku masyarakat tersebut.
Melalui pendekatan metode hearth dengan kegiatan yang dilakukan bersama masyarakat setempat khususnya para kader kesehatan dan puskesmas, mempertahankan dan memodifikasi kebiasaan-kebiasaan yang menjadi perilaku masyarakat dengan cara peningkatan pengetahuan. Kegiatan penyuluhan dan simulasi berfokus pada empat faktor yaitu : pemberian makan, pola asuh, kebersihan serta perawatan kesehatan. Kegiatan yang berlanjut dalam metode hearth yaitu dilakukan monitoring dan evaluasi yaitu para ibu mempraktekkan pengetahuan yang sudah didapatkan dalam kehidupan sehari-hari sehingga terjadi peningkatan status gizi pada balita. Hal ini ditunjukkan dengan adanya perubahan status gizi di setiap tahapan metode tungku. Pada 12 hari pertama menunjukkan kenaikan status gizi sebesar $29,4 \%$, post test ke 2 kenaikan sebesar $76,5 \%$ dan post test ke 3 $88,2 \%$. Hal ini menunjukkan pendekatan pendekatan hearth merupakan solusi efektif untuk mengatasi masalah gizi pada balita.

Hasil penelitian penelitian ini sejalan dengan penelitian yang dilakukan oleh Piroska (2011) di Universitas Walden, Minneapolis USA, menyimpulkan bahwa metode hearth dengan pendekatan hearth untuk mengurangi malnutrisi anak ternyata efektif.

Penelitian di Indonesia dilakukan oleh Sirajuddin (2011) menyatakan penerapan model tungku mampu menurunkan prevalensi anak wasting sebesar 8,29 selama 3 bulan, dan penerapan model tungku setiap wilayah akan berbeda karena tergantung penerimaan terhadap inovasi dalam pemberian makan, pengasuhan dan pengobatan sebagai pilar model tungku

Penelitian lainnya studi positive deviance dengan pendekatan Metode hearth telah dilakukan oleh Hapitria, dkk (2013) di di Astanapura Cirebon yang hasilnya pendekatan positif deviance berpengaruh pada status gizi anak dan faktor lain yang berdampak pada status gizi adalah pendidikan ibu dan usia anak. 
Luciasari dkk, (2011) melakukan penelitian terhadap faktor-faktor penyimpangan positif status gizi Balita pada keluarga miskin di kabupaten gizi-kurang rendah dan Tinggi di provinsi sulawesi selatan yang hasilnya menunjukkan status gizi balita sangat ditentukan oleh faktor sosial dan ekonomi keluarga meliputi pendidikan kepala keluarga (KK) dan ibu, penghasilan KK, jumlah anggota rumah tangga, akses air bersih, kebersihan dan sanitasi lingkungan serta morbiditas keluarga.

Menurut dahlia (2012) Keuntungam model tungku :

(1) Cepat,

(2) terjangkau oleh keluarga karena disesuaikan dengan sumber daya yang dimiliki,

(3) partisipatif setiap masyarakat saling menularkan kebiasaan yang positif, berkelanjutan karena perubahan perilaku dipraktekkan dalam kehidupan sehari-hari dan dijadikan pola hidup,

(4) asli karena pemecahan masalah menggunakan sumberdaya yang sudah ada di tempat tersebut,

(5) dapat diterima budaya setempat (6)Berdasarkan perubahan perilaku melalui penemuan (penyelidikan, pendekatan tungku (hearth)), demonstrasi (kegiatan pos gizi) dan penerapan (kegiatan pos gizi dan di rumah). Keuntungan dari metode ini juga berlaku di kecamatan cimeyan dengan adanya budaya yang sama maka peningkatan pengetahuan terhadap kesehatan serta perubahan perilaku lebih mudah ditularkan.

\section{KETERBATASAN PENELITIAN}

Jumlah sampel yang kurang refresentatif dibandingkan dengan kasus malnutrisi di Kabupaten Bandung

\section{SIMPULAN}

Pendekatan model tungku (hearth) memberikan pengaruh yang signifikant terhadap perubahan status gizi pada balita di Wilayah Kerja Puskesmas Cimenyan
Kabupaten Bandung ditunnjukkan dengan adanya perbedaan yang bermakna status gizi balita sebelum dengan setelah dilakukan intervensi.

\section{SARAN}

1. Dilakukan penelitian yang sama dengan jumlah sampel yang lebih representatif sehingga dapat mewakili wilayah kabupaten Bandung untuk mendapatkan data tentang efektifitas model Hearth

2. Sosialisasi program model Hearth ke dinas kabupaten Bandung sebagai alternatif upaya penyelesaian masalah gizi balita di wilayah kabupaten Bandung

3. Membuat sistem penghargaan untuk kader-kader yang merupakan barisan terdepan dalam menentukan keberhasilan program kesehatan khususnya program model Hearth

\section{DAFTAR PUSTAKA}

Agus, Z. 2004. Hubungan Pengetahuan dan Tindakan Penanggulangan Status Gizi BGM pada Balita di Puskesmas Nanggalo. Skripsi Unand.

Arikunto. 2010. Prosedur Penelitian (suatu pendekatan praktek). Jakarta : Rineka Cipta

Aryastami, 2011. Perbaikan gizi anak balita melalui pendekatan pendekatan tungku (hearth) : sebuah uji coba di Kabupaten Cianjur. Depkes:Jakarta

Bolles K, Speraw C, Berggren G, Lafontant JG. Ti Foyer (Hearth) CommunityBased Nuturition Activities Informed By Pendekatan Tungku (Hearth) Approach In Leogane, Haiti: A Programmatic Description. Food Nutr Bull 2002; 23 (Suppl 4): 11-7.

Core Gorup, PCI, 2003. Perilaku dalam Postive Deviance.

Dahlia, 2012. The Effect Of Positive Deviance Approach Toward The Improvement Of Nutrition Status Of ChildrenUnder Five Years Media Gizi Masyarakat Indonesia, Vol.2, No.1, Agustus $2012: 1-5$ 
Depkes, 2012. Sambutan Menkes pada Buku Pedoman Penangan Gizi Buruk. Jakarta

Departemen Kesehatan RI, 2010. Penilaian antropometri status gizi. Available at http://www.gizi.depkes.go.id, diakses pada tanggal 26 Februari 2013 Pukul 15.45WIB

Fisher, dkk. 2012. Hubungan Tingkat Pengetahuan Ibu Tentang Gizi Dengan Status Gizi Balita Di Desa Sioban Kabupaten Kepulauan Mentawai.

Hapitria, dkk. 2011. Positive Deviance in Under-five Nutritional Status. Berita Kedokteran Masyarakat, Vol. 27, No. 4, Desember 2011

Luciasari, dkk 2011. Factors Of Positive Deviance In Nutritional Status Of Under-FivesAmong Poor Family In Low- \& High-Undernutrition Districts In Sulawesi Selatan Province, PGM 2011, 34(2):114-122

Marsh DR, Schroeder DG.2008. The Hearth Approach To Improve Health Outcomes: Experience And Evidence From The Field. Food Nutr Bull 2002; 23 (suppl 4): 5-8.
Rahayu. 2001. Psikologi Perkembangan.Yogyakarta: Gadjah Mada UniversityPress;

Riskesdas, 2012. Riset Kesehatan Dasar Nasional.Jakarta.www.riskesda.litbang .depkes.go.id (diakses pada tanggal 26 Februari 2013 pukul 17.37 WIB). Sirajuddin.(2005). Model Tungku (Hearth) Terbukti Mampu Mengeliminasi Kasus Kurang Gizi Secara Berkelanjutan. Tersedia di : http://www.gizi net.com. Diakses pada 26 Februari, 2013)

Piroska A. Bisits Bullen,2011. The Positive Deviance/Hearth Approach to Reducing Child Malnutrition; Systematic Revieu, Tropical Medicine and Internasional Health. Available at : http:onlinelibrary,wiley.com. .

UNICEF, 2012. Kematian Balita Di Indonesia. Jakarta. www.Unicef.org (diakses pada tanggal 26Februari 2013 pukul 17.37 WIB). 